\title{
Kinetics of Phosporus Removal from Laundry Wastewater in Constructed Wetlands with Equisetum hymale
}

\author{
Febri Eko Wahyudianto ${ }^{*}$, Nur Indradewi Oktavitri', Sucipto Hariyanto² \\ 1 Study Program of Environmental Engineering, Faculty Science and Technology, Universitas Airlangga, \\ Surabaya 60115, Indonesia \\ 2 Study Program of Biology, Faculty Science and Technology, Universitas Airlangga, Surabaya 60115, Indonesia \\ * Corresponding author's e-mail: febri.eko.w@fst.unair.ac.id
}

\begin{abstract}
The objective of this study was to determine the capacity, process, and kinetics of phosphorus $\left(\mathrm{PO}_{4}-\mathrm{P}\right)$ nutrients pollutant removal in constructed wetlands with Equisetum hymale plants. This research was conducted by using a batch system constructed wetlands with detention time variation of 1-5 days and using gravel, sand, and soil as the media. The laundry wastewater used for this research was collected from commercial activity in Surabaya city. The results of this research showed that the removal efficiency of $\mathrm{PO}_{4}-\mathrm{P}$ using the constructed wetlands with Equisetum hymale was between the range of $95.49-99.43 \%$. The removal process was done by screening-adsorption, and the sedimentation mechanisms from the media, and the biosorpsion by the plants was shown by the increasing content of $\mathrm{PO}_{4}-\mathrm{P}$ in soil and plants, which amounted to $14.80 \%$ and $9.23 \%$ respectively. The removal kinetics of $\mathrm{PO}_{4}-\mathrm{P}$ was according to the second-order model with value of $\mathrm{R}^{2}=0.99$.
\end{abstract}

Keywords: constructed wetlands, kinetics, Equisetum hymale

\section{INTRODUCTION}

The issues in water pollution are caused not only by the amount of hazardous contents intake in the water but can also be caused by the nutrient pollutants that percolate into the water source. Phosphorus is one of the nutrients that could pollute the water in environment to the greatest extent, that could cause eutrophication in the water sources (Le Moal et al., 2019). The phosphorus contents that infiltrate into the water could be categorized as point source or non-point source. The example of phosphorus source that come from point source are the effluent of industrial or laundry and domestic activities, while non-point phosphorus sources could be found in the phosphorus diffusion process in agricultural activities (Di Luca et al., 2017; Vymazal, 2014). At present, laundry and domestic activities are the main phosphorus producers, especially in large cities in Indonesia because of the increasing population and few wastewater treatment plants.
The laundry and domestic wastewater need to be treated by reducing the nutrient which got into the water source. One of the efforts to treat laundry wastewater is by using the constructed wetlands concept (Vymazal, 2014). Constructed wetlands have a few benefits which are the low operational costs, easy and feasible operation, contribution to the improvement of the landscape aesthetics, and providing habitat for many other organisms (Meng et al., 2014; Yeh et al., 2015; Zhang et al., 2014; Jóźwiakowski et al., 2018). Those benefits could justifz the application of constructed wetlands for treating laundry wastewater in populous areas.

There are many other studies related to the use of constructed wetlands for treating wastewater, which aim at determining the compatible and suitable plants species for constructed wetlands unit. For example, the Typha, Pragmites australis, and Sciprus species can be used in treating domestic wastewater (Timotewos et al., 2017). On other hand, there are many factors that could 
affect the process in constructed wetlands, such as the substrate type, substrate capacity, hydraulic load and retention time, water depth, and feeding mode in constructed wetlands (Meng et al., 2014; Sirianuntapiboon et al., 2006; Wu et al., 2015). Therefore, the aim of this research was to determine the capacity, process, and kinetics of phosphorus $\left(\mathrm{PO}_{4}-\mathrm{P}\right)$ nutrients removal in constructed wetlands with Equisetum hymale plants.

\section{MATERIAL AND METHODS}

\section{Constructed wetlands reactors}

The constructed wetlands reactors consist of 10 reactors with variation of 5 different hydraulic retention times (each variation with 2 replications). The reactors were made of pots with length, width, and height of $80 \mathrm{~cm}, 20 \mathrm{~cm}$, and $25 \mathrm{~cm}$ respectively, and the volume of 40 liters. The media composition in the constructed wetlands reactors consisted of gravel $(\phi 20 \mathrm{~mm})$, sand $(\phi 0.4-2 \mathrm{~mm})$, and soil with the height of each media amounting to $3 \mathrm{~cm}, 3 \mathrm{~cm}$, and $15 \mathrm{~cm}$, respectively. Each reactor consisted of 4 groups (each group comprised 150 plants) of Equisetum hymale plants, which was obtained from a nursery in East Java. The scheme of constructed wetlands is shown in Figure 1. The sampling point in this reactor was located $2.5 \mathrm{~cm}$ from the bottom of reactor and the water level was about $3 \mathrm{~cm}$ above media. The laundry wastewater used for this research was collected from commercial laundry in Surabaya city with characteristics shown in Table 1. The constructed wetlands reactors were placed inside a greenhouse available in Biology Department, Universitas Airlangga under normal conditions, without any lightning control.

\section{Sampling and analysis}

The samples were taken every day for 5 days, continuously, in a glass container and kept inside the cold-storage box at a temperature of $4^{\circ} \mathrm{C}$ before the analysis. The samples taken were analyzed for the $\mathrm{PO}_{4}-\mathrm{P}$ content with chloride Stannous method which referred to the standard methods for examination of water and waste water 4500-P D (APHA, 2012) using spectrophotometer (Broco). Soil, plant's stems and roots used in this research were taken as random samples on day 5 to be analyzed for phosphorus content. The soil, stems, and roots were dried using an oven (Memmert, Germany) at a temperature of $105^{\circ} \mathrm{C}$ for 24 hours until the constant mass was achieved. The phosphorus content in soil and plants ( $\mathrm{mg} / \mathrm{kg}$ )was analyzed using P.Olsen method. The calculation of removal percentage could be calculated with the equation (1) (Olguín et al., 2017):

$$
\begin{gathered}
\text { Removal }(\%)= \\
=\frac{\text { Inletconcentration }- \text { Outletconcentration }}{\text { Inletconcentration }} \times 100 \%
\end{gathered}
$$

\section{Batch kinetics experiment}

Acclimatization of Equisetum hymale plants was conducted for 7 days after planting using tap water. The day after acclimatization, the water was drained to be replaced with the laundry wastewater until the media were submerged in the wastewater to about $3 \mathrm{~cm}$ above media. The kinetics attempt was conducted using batch method with retention time of $1,2,3,4$, and 5 days for each constructed wetland unit. First-order and second-order pollutant model equations could be used to find the kinetics model in the constructed wetlands with Equisetum hymale which was expressed in equation 2 and 3 (Farzadkia et al., 2015).

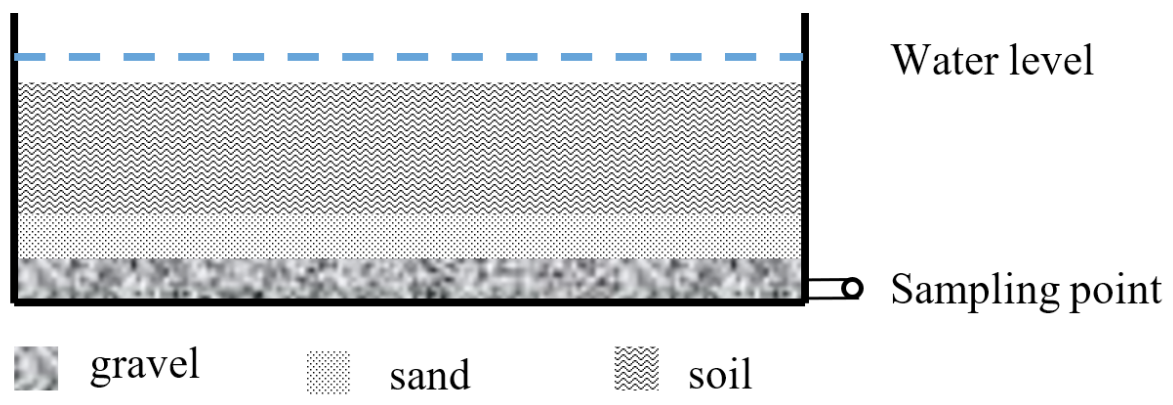

Figure 1. Constructed wetlands reactor 
Table 1. Characteristic of laundry waste water

\begin{tabular}{|l|c|c|}
\hline \multicolumn{1}{|c|}{ Parameters } & Concentration & Effluent Standart* \\
\hline Temperature $\left({ }^{\circ} \mathrm{C}\right)$ & $29-31$ & - \\
\hline $\mathrm{pH}$ & $6.9-7.6$ & $6-9$ \\
\hline Phospat & 10.067 & 10 \\
\hline $\mathrm{COD}$ & 861.54 & 250 \\
\hline TSS & 1040 & 100 \\
\hline Surfactan Anionic & 78.13 & 10 \\
\hline
\end{tabular}

* Regulation Governor East Java Indonesia No. 72/2013 concerning Waste Water Quality of Industry.

$$
\frac{S i-S e}{H R T}=k_{1} S e
$$

According to the equation (2) $\mathrm{S}_{\mathrm{i}}$ is the influent concentration $(\mathrm{mg} / \mathrm{L}), \mathrm{S}_{\mathrm{e}}$ is the effluent concentration $(\mathrm{mg} / \mathrm{L})$, HRT is the retention time (day), and $\mathrm{k}_{1}$ is the first-order kinetics coefficient.

$$
\frac{H R T}{E}=n \times H R T+m
$$

According to the equation (3) $\mathrm{E}$ is the value of $\mathrm{Si}-\mathrm{Se} / \mathrm{Si}$ and $\mathrm{n}$ and $\mathrm{m}$ are the coefficients in which second-order coefficient (ks) is equal to $\mathrm{Si} / \mathrm{m} \times \mathrm{X}$.

\section{RESULT AND DISCUSSION}

\section{Nutrients removal capacity and process}

The phosphorus removal capacity in constructed wetlands with Equisetum hymale was calculated with equation (1) by comparing the value between the initial concentration value and final concentration value in each reactor with variation of retention time. The result of removal capacity analysis is as shown in Figure 2. The initial concentration value of $\mathrm{PO}_{4}-\mathrm{P}(\mathrm{Si})$ in laundry wastewater used in this research $10.067 \mathrm{mg} / \mathrm{L}$. The wastewater treatment using Equisetum hymale in constructed wetlands could decrease the $\mathrm{PO}_{4}-\mathrm{P}$ final concentration (Se) to $0.049-0.454 \mathrm{mg} / \mathrm{L}$ with the removal efficiency up to $95.49-99.51 \%$.

The results in Figure 2 showed that the highest $\mathrm{PO}_{4}-\mathrm{P}$ removal capacity was at retention time of day 4 , which was up to $99.51 \%$. This value showed a higher result than one in the research by Di Luca (2017), in which the constructed wetlands could decrease phosphorus content to $70.5 \%$. Constructed wetlands could reduce total phosphorus as well up to $79,5 \%$ in the case of treating artificial domestic wastewater (Gupta et al., 2016). By using green rooftop water recycling system, constructed wetlands could even reduce phosphorus to the maximum degree up to $92 \%$ (Ramprasad et al., 2017). The removal of $\mathrm{PO}_{4}-\mathrm{P}$ in constructed wetlands was affected by the retention time of waste water treatment as well (Olguín et al., 2017; Wu et al., 2015). The results from this research showed that longer retention time could increase the removal capacity. The results obtained corresponded to the prior research that had been conducted, which related to the influence of detention time in which 4 days retention time did not only contribute to the maximum removal capacity but also could keep the removal capacity stable (Ghosh and Gopal, 2010).

The phosphorus nutrients removal process from laundry wastewater using constructed wetlands with Equisetum hymale was involved a few components that were found in the reactor, which

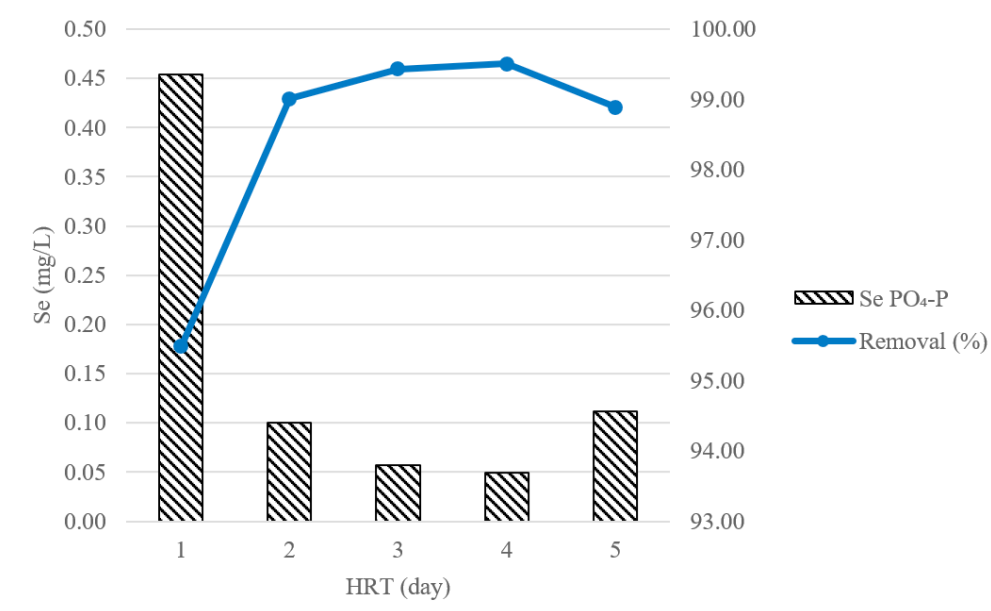

Figure 2. Removal capacity of phosphorus $\left(\mathrm{PO}_{4}-\mathrm{P}\right)$ from constructed wetlands with Equisetum hymale 
included the soil media and plants. The analysis results from the media and plants in constructed wetlands were expressed in Table 2. The table showed that the increase of the phosphorus content occurred in the soil and plants, both below the ground part such as the roots and the surface part such as the stems. The highest phosphorus concentration was shown in the stems of Equisetum hymale which was $15.35 \%$; in soil was $14.80 \%$; while in roots was $9.23 \%$.

The phosphorus removal process that occurred in the plants and soil showed that the phosphorus in the laundry wastewater could be taken up by Equisetum hymale. Phosphorus itself is one of the macro-nutrients that is needed for the plants to support their growth (Abdolzadeh et al., 2010). Plants could adsorb $\mathrm{PO}_{4}-\mathrm{P}$ that came from a dilution soaked into the soil through their roots by the diffusion mechanism (Smith, 2002). In turn, the $\mathrm{PO}_{4}-\mathrm{P}$ removal that occurred in the constructed wetlands media, especially in the soil, could happen because of a few factors such as the bonds with organic matters and the media's alkalinity condition (Di Luca et al., 2017). Beside all those factors, the phosphorus removal in media was also possible because of adsorption process

Table 2. Phosphorus accumulation analysis in soil and plants

\begin{tabular}{|l|c|c|c|c|}
\hline Parameter(s) & Unit & Before & After & $\begin{array}{c}\text { Accumulation } \\
(\%)\end{array}$ \\
\hline Soil & $\mathrm{mg} / \mathrm{kg}$ & 9.39 & 10.78 & 14.80 \\
\hline $\begin{array}{l}\text { Plant (Above } \\
\text { ground) }\end{array}$ & $\mathrm{mg} / \mathrm{kg}$ & 38.81 & 44.73 & 15.25 \\
\hline $\begin{array}{l}\text { Plant (Below } \\
\text { ground) }\end{array}$ & $\mathrm{mg} / \mathrm{kg}$ & 220.98 & 241.37 & 9.23 \\
\hline
\end{tabular}

and sedimentation that occurred in constructed wetlands media (Merino-Solís et al., 2015). Therefore, constructed wetlands with Equisetum hymale could remove phosphorus by absorption, adsorption, and sedimentation mechanisms in the plants and media.

\section{Kinetics model}

In this kinetics study, two models used were first-order kinetic and second-order kinetic (grove model) models which are described in equation (2) and (3) (Farzadkia et al., 2015). Those two models were used to determine the tendency process that occurred in constructed wetlands with Equisetum hymale in reducing the $\mathrm{PO}_{4}-\mathrm{P}$ content from laundry wastewater. The results of models from the batch experiment in constructed wetlands with Equisetum hymale were expressed in Figures 3 and 4. In Figure 3, the kinetics model from $\mathrm{PO}_{4}-\mathrm{P}$ removal indicated the correlation between effluent concentration value (Se) and concentration reduction value ( $\mathrm{Si}-\mathrm{Se}$ ) for each variation time (HRT). The results showed that the linear regression $\mathrm{y}=$ $16.819 x+1.8922$ with regression coefficient $\left(\mathrm{R}^{2}\right)$ was 0.8569 . In turn, in Figure 4, the second-order kinetic (grove model) gave linear regression of $y=1.0017 x+0.0268$ with regression coefficient $\left(\mathrm{R}^{2}\right)$ of 0.9999 . With the results obtained, it could be determined that the $\mathrm{PO}_{4}-\mathrm{P}$ removal process which occurred in constructed wetlands with Equisetum hymale had tendencies towards the second-order kinetic model. It indicated that the process was done chemically. The mechanism that occurred in $\mathrm{PO}_{4}-\mathrm{P}$ removal in other studies indicated that phosphorus removal referred to the

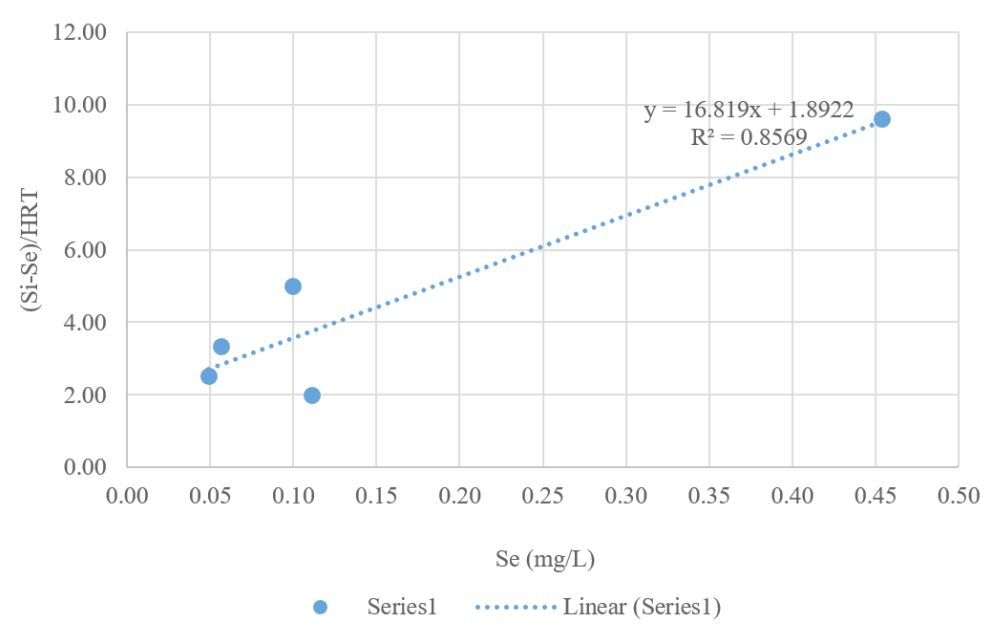

Figure 3. The first-order kinetic model 


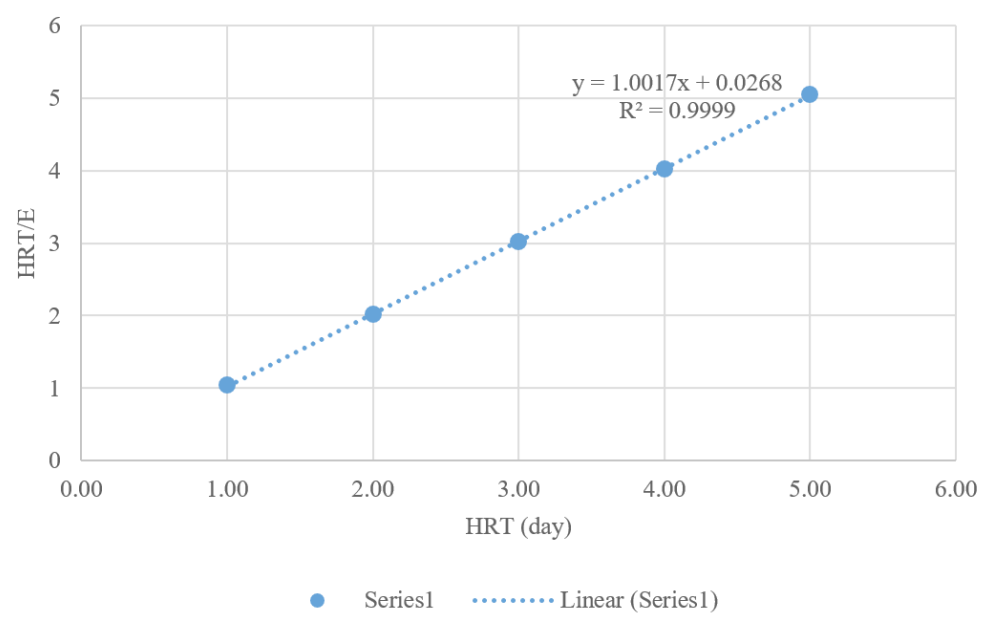

Figure 4. The second-order kinetic model (grove model)

second-order kinetic as well (Pérez et al., 2014). The second-order kinetic model could also be applied to the ammonium nitrogen removal using constructed wetlands (Zhu et al., 2011) and $17 \alpha$-methyltestosterone removal with Salvinia cucullata (Adnan and Thanasupsin, 2016).

\section{CONCLUSIONS}

Constructed wetlands with Equisetum hymale could reduce the nutrients pollutant in the form of $\mathrm{PO}_{4}-\mathrm{P}$ with the removal efficiency of up to $95.49-99.43 \%$. The considered process involved screening-adsorption, sedimentation, and biosorpsion in Equisetum hymale plants and occurred by referring to the second-order kinetic model $\left(\mathrm{R}^{2}>0.9999\right)$.

\section{Acknowledgements}

This study was supported by Faculty of Science and Technology, Universitas Airlangga.

\section{REFERENCES}

1. Abdolzadeh, A., Wang, X., Veneklaas, E.J., Lambers, H., 2010. Effects of phosphorus supply on growth, phosphate concentration and cluster-root formation in three Lupinus species. Annals of Botany. vol. $105,365-374$.

2. Adnan, F., Thanasupsin, S.P., 2016. Kinetic studies using a linear regression analysis for a sorption phenomenon of 17a-methyltestosterone by Salvinia cucullata in an active plant reactor. Environmental Engineering Research. vol. 21, 384-392.
3. APHA, 2012. Standard Methods for the Examination of Water and Wastewater, 21th ed. American Public Health Association, Washington DC, USA.

4. Di Luca, G.A., Maine, M.A., Mufarrege, M.M., Hadad, H.R., Pedro, M.C., Sánchez, G.C., Caffaratti, S.E., 2017. Phosphorus distribution pattern in sediments of natural and constructed wetlands. Ecological Engineering. vol. 108, 227-233.

5. Farzadkia, M., Ehrampush, M.H., Mehrizi, E.A., Sadeghi, S., Talebi, P., Salehi, A., Kermani, M., 2015. Investigating the efficiency and kinetic coefficients of nutrient removal in the subsurface artificial wetland of Yazd wastewater treatment plant. Environmental Health Engineering and Management Journal. vol. 2, 23-30.

6. Ghosh, D., Gopal, B., 2010. Effect of hydraulic retention time on the treatment of secondary effluent in a subsurface flow constructed wetland. Ecological Engineering. vol. 36, 1044-1051.

7. Gupta, P., Ann, T.W., Lee, S.M., 2016. Use of biochar to enhance constructed wetland performance in wastewater reclamation. Environmental Engineering Research. vol. 21, 36-44.

8. Jóźwiakowski K., Bugajski P., Kurek K., de Carvalho M., Almeida M.A., Gajewska M., Siwiec T., Borowski G., Czekała W., Dach J., Gajewska M. 2018. The efficiency and technological reliability of biogenic compounds removal during long-term operation of a one-stage subsurface horizontal flow constructed wetland. Separation and Purification Technology. vol. 202, 216-226.

9. Le Moal, M., Gascuel-Odoux, C., Ménesguen, A., Souchon, Y., Étrillard, C., Levain, A., Moatar, F., Pannard, A., Souchu, P., Lefebvre, A., Pinay, G., 2019. Eutrophication: A new wine in an old bottle? Science of The Total Environment. vol. 651, 1-11.

10. Meng, P., Pei, H., Hu, W., Shao, Y., Li, Z., 2014. How to increase microbial degradation in constructed wetlands: Influencing factors and im- 
provement measures. Bioresource Technology. vol 157, 316-326.

11. Merino-Solís, M., Villegas, E., de Anda, J., LópezLópez, A., 2015. The Effect of the Hydraulic Retention Time on the Performance of an Ecological Wastewater Treatment System: An Anaerobic Filter with a Constructed Wetland. Water. vol. 7, 1149-1163.

12. Olguín, E.J., Sánchez-Galván, G., Melo, F.J., Hernández, V.J., González-Portela, R.E., 2017. Long-term assessment at field scale of Floating Treatment Wetlands for improvement of water quality and provision of ecosystem services in a eutrophic urban pond. Science of The Total Environ. vol. 584-585, 561-571.

13. Pérez, M.M., Hernández, J.M., Bossens, J., Jiménez, T., Rosa, E., Tack, F., 2014. Vertical flow constructed wetlands: Kinetics of nutrient and organic matter removal. Water Science and Technolohy. vol. 70, 76-81.

14. Ramprasad, C., Smith, C.S., Memon, F.A., Philip, L., 2017. Removal of chemical and microbial contaminants from greywater using a novel constructed wetland: GROW. Ecological Engineering. vol. 106, 55-65.

15. Sirianuntapiboon, S., Kongchum, M., Jitmaikasem, W., 2006. Effects of hydraulic retention time and media of constructed wetland for treatment of domestic wastewater. Journal of Agricultural Research. vol. 1, 27-37.
16. Smith, F.W., 2002. The phosphate uptake mechanism. Plant and Soil. vol. 245, 105-114.

17. Timotewos, M.T., Kassa, K., Reddythota, D., 2017. Selection of mesocosm to remove nutrients with constructed wetlands. Journal of Ecological Engineering. vol. 18, 42-51.

18. Vymazal, J., 2014. Constructed wetlands for treatment of industrial wastewaters: A review. Ecological Engineering. vol. 73, 724-751.

19. Wu, H., Zhang, J., Ngo, H.H., Guo, W., Hu, Z., Liang, S., Fan, J., Liu, H., 2015. A review on the sustainability of constructed wetlands for wastewater treatment: Design and operation. Bioresource Technology. vol. 175, 594-601.

20. Yeh, N., Yeh, P., Chang, Y.H., 2015. Artificial floating islands for environmental improvement. Renewable and Sustainable Energy Reviews. vol. 47, 616-622.

21. Zhang, D.Q., Jinadasa, K.B.S.N., Gersberg, R.M., Liu, Y., Ng, W.J., Tan, S.K., 2014. Application of constructed wetlands for wastewater treatment in developing countries - A review of recent developments (2000-2013). Journal of Environmental Management. vol. 141, 116-131.

22. Zhu, W.L., Cui, L.H., Ouyang, Y., Long, C.F., Tang, X.D., 2011. Kinetic Adsorption of Ammonium Nitrogen by Substrate Materials for Constructed Wetlands. Pedosphere. vol.21, 454-463. 